\title{
The beneft of using a low dose calcium channel blocker in a patient with idiopathic pulmonary hypertension
}

\author{
Olga Nedeljković-Arsenović1 ${ }^{1}$, Marija Boričić-Kostić², Olivera Ninković-Mrđenovački \\ Ivana Nedeljkovićc ${ }^{1,2}$, Biljana Parapid ${ }^{1,2}$, Bosiljka Vujisić-Tešić1,2, Marko Banović1,2 \\ ${ }^{1}$ School of Medicine, University of Belgrade, dr Subotića 8, Belgrade, Serbia; ${ }^{2}$ Clinic of Cardiology, Clinical Center of Serbia, \\ Višegradska 26, Belgrade, Serbia; ${ }^{3}$ Institute of Public Health Sabac, Jovana Cvijica 1, Sabac, Serbia
}

Abstract

\begin{abstract}
Introduction: Pulmonary arterial hypertension is defined by hemodynamic and pathophysiological changes of increased resting mean pulmonary arterial pressure $\geq 25 \mathrm{mmHg}$ estimated by right heart catheterisation.

Case report: We describe a 44-year-old woman who presented for evaluation 13 years after being diagnosed with primary pulmonary hypertension. Over that extended period of time, she did not develop any changes in her coronary or pulmonary vascular measurements as documented by repeat catheterization. She did not have signs of systemic connective tissue disease. Throughout this time, she was managed with continuous medical treatment of low-doses of a Ca-channel antagonist (nifedipine $10 \mathrm{mg}$ twice per day) along with oral anticoagulant therapy. Her ongoing complaints were of fatigue when engaged in heavy physical activity, but there was no progression of symptoms. She also occasionally felt symptoms of increased heart rate and syncope. Auscultation revealed a systolic murmur along the left parasternal edge and an accented second sound of the pulmonary artery. Electrocardiography showed sinus rhythm and incomplete right bundle branch block. Echocardiography was consistent with signs of pulmonary hypertension.

Conclusion: A small number of patients with pulmonary hypertension have a good prognosis with treatment with modest doses of calcium blockers as seen in our patient who has had a stable course of disease for many years.
\end{abstract}

Key Words Primary pulmonary hypertension, calcium channel blockers, cardiac catheterization, echocardiography

\section{Introduction}

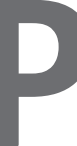

ulmonary arterial hypertension (PAH) is a chronic, progressive disease of the pulmonary vasculature resulting in right ventricular failure and death, if untreated ${ }^{1}$. PAH is defined as a hemodynamic and pathophysiological condition of increased resting mean pulmonary arterial pressure (mPAP) $\geq 25 \mathrm{mmHg}$; pulmonary capillary wedge pressure or left ventricular end diastolic pressure $\leq 15 \mathrm{mmHg}$; and pulmonary vascular resistance $(P V R) \geq 3$ Wood units estimated by right heart catheterisation ${ }^{2}$. A registry of patients with PAH in France found a prevalence of about 15 cases per million population ${ }^{3}$.

Idiopathic pulmonary arterial hypertension (IPAH) or primary pulmonary hypertension (PPH) is rare and difficult progressive disease with a prevalence of about 6 per million ${ }^{4}$ characterized by elevated pulmonary artery pressure with no apparent cause ${ }^{5}$. IPAH occurs at a female-to-male ratio ranging from 2-9:1, depending on the treatment center sampled. The reasons for this female predilection remain unknown. Typically, younger women of childbearing age between ages 21 and 40 develop IPAH ${ }^{6,7}$. However, IPAH can also affect individuals in their fifth and sixth decades of life or older ${ }^{6}$.

Based on data from an American Registry, idiopathic hypertension represent $40 \%$ of $\mathrm{PAH}$, while pulmonary hypertension $(\mathrm{PH})$ associated with other diseases is found in about $50 \%$ of cases ${ }^{8}$. In developing countries, schistosomiasis is a common cause of PAH, and the estimated number of registered cases worldwide is about 200 million $^{9}$.

According to the most recent classification of pulmonary hypertension based on clinical and pathophysiological characteristics, PAH is divided into 5 groups: 1) idiopathic PAH, 2) PAH due to left heart disease, 3) PAH due to lung diseases and hypoxia, 4) PAH due to chronic thromboembolism, 5) PAH associated with multifactorial diseases (systemic connective tissue diseases, hematological, and metabolic disorders) ${ }^{10}$.

PPH usually develop slowly. Patients remain minimally symptomatic for many years. Most patients with PAH present with exertional dyspnea that progresses 


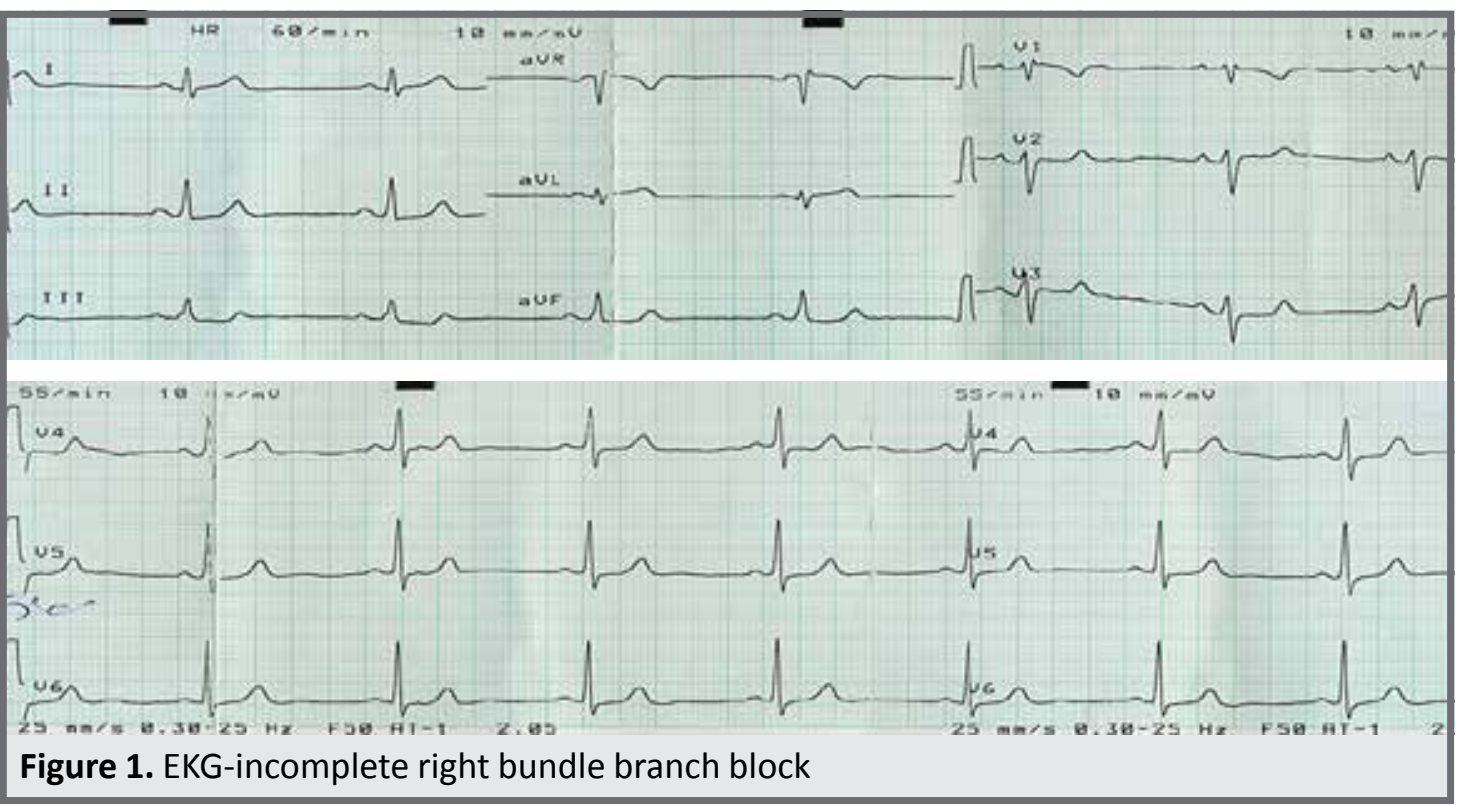

over months or even years. Exertional chest pain, syncope, and lower extremity edema are indicative of more severe pulmonary hypertension with impaired right heart function. Diagnosis is often delayed due to the subtle findings on physical examination and the nonspecific symptoms experienced by most patients $\mathrm{s}^{3,11,12}$.

Establishing the diagnosis and etiology of $\mathrm{PAH}$ requires a comprehensive evaluation that includes pulmonary function testing, connective tissue disease serology, echocardiography, cardiac catheterization, and tests to exclude chronic thromboembolic disease. Echocardiography is often the first diagnostic test to evaluate for the possibility of pulmonary hypertension ${ }^{13}$. Once the diagnostic evaluation has suggested $\mathrm{PAH}$, right heart catheterization is required to confirm the presence and to determine the severity of pulmonary hypertension, to exclude left-sided heart disease or potentially correctable intracardiac left-to-right shunting, and to perform acute vasodilator testing ${ }^{14,15,16}$.

\section{Case report}

We present a clinical case of 44 year-old woman, former smoker, obese, with two children who came for cardiac examination 13 years after she had primary pulmonary hypertension initially diagnosed. Her initial evaluation then included right heart catheterization, selective pulmonary angiography and selective coronary angiography. There were no significant changes found at that time in her coronary arteries nor disorders in the pulmonary vascular network. However, high pressures in right heart pulmonary artery (PA) were registered (100/40-65 mmHg), along with hypertention of the right ventricule (RV) $(95 / 0-10 \mathrm{mmHg})$ and elevated capillary wedge pressures $(20 / 6-12 \mathrm{mmHg})$. She was evaluated for the presence of systemic connective tissue disease, which was excluded. On echocardiography, she was found to have an enlarged PA $(4.2 \mathrm{~cm}$ diameter) and its branches (left PA $2.1 \mathrm{~cm}$ and right PA $2.0 \mathrm{~cm}$ ). From then until now, the patient has been on the same medical treatment of low-doses of a Ca channel antagonist (nifedipine $2 \times 10 \mathrm{mg}$ ) along with oral anticoagulant therapy, steady state, with no progression of symptoms. She has felt tired only during times of higher physical activity, and has sometimes felt symptoms of increased heart rate and syncope. Auscultation revealed systolic murmur along the left parasternal edge and accented second tone of the pulmonary artery. Electrocardiography (ECG) showed sinus rhythm, with a normal electrical axis and incomplete right bundle branch block (Figure 1). Echocardiography pointed out that the right ventricle was of normal diameter, with hypertrophic walls, good contractility, and an enlarged pulmonary artery with its branches (Figures 2,3,4). Systolic pressure in the right ventricle could not be estimated by Doppler due to a small amount of tricuspid regurgitation, but all other echocardiographic signs of pulmonary hypertension were noted (Figure 5). Catheterization was redone and registered pressures were unchanged from the examination done 13 years earlier (PA pressure 60/40-58 $\mathrm{mmHg}$, RV pressure $70 / 0-10 \mathrm{mmHg}$, capillary wedge pressure 17/12-14 $\mathrm{mmHg}$ ).

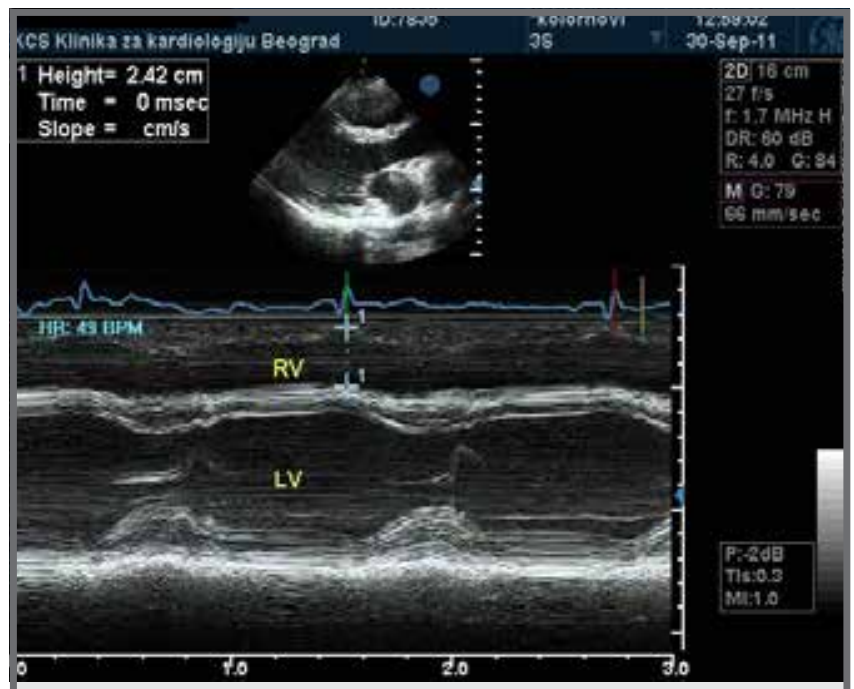

Figure 2. Right ventricle normal size 


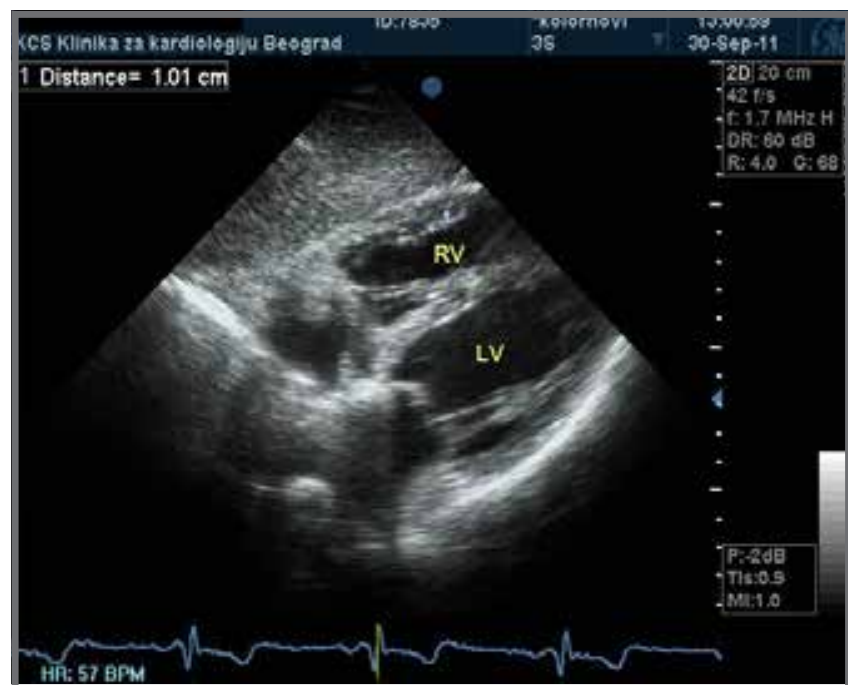

Figure 3. Right ventricle hypertrophic walls

\section{Discussion}

Modern drug therapy can lead to a significant improvement in patients with pulmonary hypertension with little change symptomatic status and a slower rate of clinical deterioration ${ }^{17}$. Pharmacologic agents used in the treatment of PAH include calcium-channel blockers $(\mathrm{CaCB})$, prostanoids, endothelin antagonists, and phosphodiesterase type 5 inhibitors. These agents all have pulmonary vasodilatory effects and all except $\mathrm{CaCBs}$ also have antiproliferative properties ${ }^{13}$. Only $10-15 \%$ of patients with all types of pulmonary hypertension seem to respond favourably to high-dose vasodilators such as $\mathrm{CaCBs}$ and these drugs are used as standard therapy in $\mathrm{PPH}$. Retrospective studies have shown improved survival in patients with $\mathrm{PPH}$ who are anticoagulated but there are no randomized controlled trials (RCT) published with data available to support this therapy. Consensus based on elinical experience, however, suggests that anticoagulation is a useful treatment, supporting the idea that there is a thrombotic component to the illness ${ }^{5,18}$.

Supplemental oxygen can help symptomatically with exercise tolerance. Diuretics are used to treat right heart failure and remove peripheral edema, along with digoxin as a positive inotrope. There are no convincing trial data to support their use but clinical experience suggests that these treatments are beneficial ${ }^{5}$.

In the past few years, treatment of PAH has undergone an extraordinary evolution. A meta-analysis performed assessing 23 RCTs in $\mathrm{PAH}$ patients reports a 43\% decrease in mortality and a $61 \%$ reduction in hospitalizations in patients treated with specific drug therapies vs. patients randomized to placebo ${ }^{19}$.

The enthusiasm for the use of CaCBs in IPAH dates back to 1992. with the publication of a study that demonstrated 95\% 5-year survival in a very select group of patients with IPAH who exhibited an acute vasodilator response to $\mathrm{CaCBs}^{20}$.

The CaCBs that have been predominantly used in reported studies are nifedipine, diltiazem, and amlodipine, with particular emphasis on the first two ${ }^{(21)}$. The daily doses of these drugs that have shown efficacy in IPAH are relatively high, 120-240 mg for nifedipine,

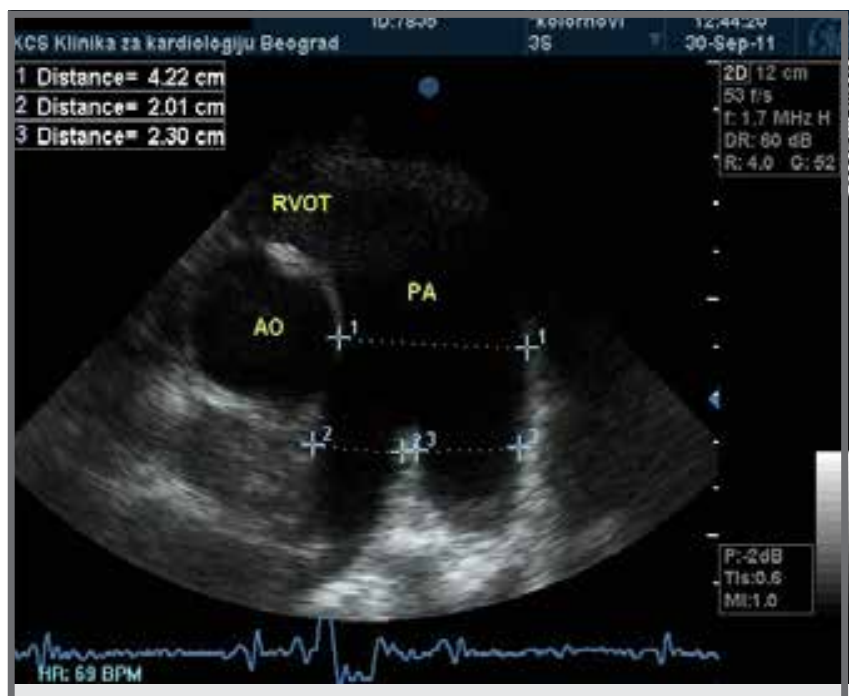

Figure 4. Enlarged pulmonary artery and its branches

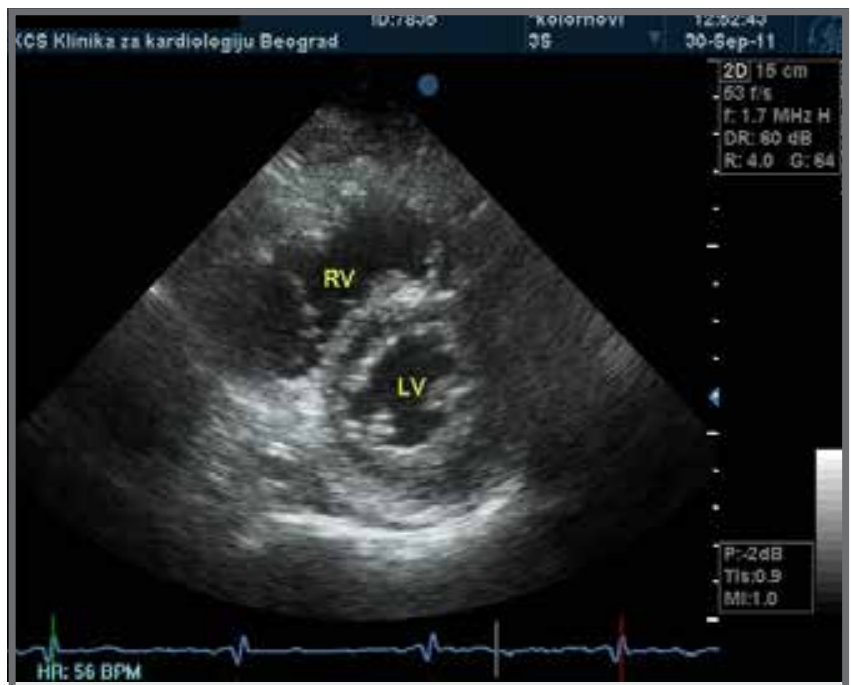

Figure 5. D-shape, pulmonary hypertension

240-720 mg for diltiazem, and up to $20 \mathrm{mg}$ for amlodipine. It is advisable to start with a low dose, e.g. $30 \mathrm{mg}$ of slow release nifedipine twice a day, $60 \mathrm{mg}$ of diltiazem three times a day, or $2.5 \mathrm{mg}$ of amlodipine once a day and increase cautiously and progressively to the maximum tolerated dose ${ }^{13,22}$

In contrast, our patient has a stable course of disease for many years at a low dose of Ca blockers $(2 \times 10 \mathrm{mg}$ nifedipine).

CaCBs remain a treatment option only for patients with a positive vasodilator challenge. In a retrospective study, $12.6 \%$ of patients with idiopathic PAH had evidence of acute pulmonary vasoreactivity and received CaCB therapy. Of the entire cohort of patients, only $6.8 \%$ had long-term response ${ }^{21}$. Similarly, in a previous report of the French registry, only $10.3 \%$ of patients with idiopathic $\mathrm{PAH}$ had a positive vasoreactivity test ${ }^{3}$.

\section{Conclusion}

The treatment approach for $\mathrm{PAH}$ patients should be based after a compound strategy of evaluation of severity, assessment of vasoreactivity, estimation of efficacy, and based on treatment outcomes from a combination 
of different drugs plus interventions ${ }^{17}$.

Treatment goals in $\mathrm{PAH}$ patients are numerous. Improving the patients symptoms, which commonly include dyspnea and fatigue, are principal. Also, a very important aim of therapy is to reverse or prevent progression of the disease, decrease the number of hospitalizations, normalize cardiac output and prevent the need for lung transplantation ${ }^{2}$.

A variety of pharmaceutical substances may play roles as mediators through a final common pathway of pulmonary angiogenesis and may therefore be appealing therapeutic targets. These include vasoactive intestinal polypeptide ${ }^{23}$, platelet-derived growth factor ${ }^{24}$, serotonin and its receptors and transporter ${ }^{25}$, and Rho kinase inhibitors ${ }^{26}$. Clinical trials for many of these substances are underway ${ }^{13}$.

Despite the existence of a new generation of expensive drugs and the multiplex pathophysiology of the disease, our patient has thus far had an excellent response to classical therapy of very low doses of Cablockers (Nifedipine $2 \times 10 \mathrm{mg}$ ). She represents one of the rare cases of patients $(6.8 \%$ according to the current literature), who has a good response to vasodilator therapy without worsening either of symptoms or pulmonary hypertension parameters over a prolonged period of time (over 13 years).

\section{References}

1. Porhownik NR, Bshouty Z. Pulmonary arterial hypertension: A serious problem. Perspect Cardiol 2007;23:33-40

2. McLaughlin VV, Archer SI, Badesch DB, et al. ACCF/AHA 2009 expert consensus document on pulmonary hypertension: A report of the American College of Cardiology Foundation Task Force on Expert Consensus Documents and the American Heart Association: developed in collaboration with the American College of Chest Physicians, American Thoracic Society, Inc., and the Pulmonary Hypertension Association. Circulation 2009;119:2250-94.

3. Humbert $\mathrm{M}$, Sitbon $\mathrm{O}$, Chaouat $\mathrm{A}$, et al. Pulmonary arterial hypertension in France: results from a national registry. Am J Respir Crit Care Med 2006;173:1023-30

4. Rudarakanchana N, Trembath RC, Morrell NW. New insights into the pathogenesis and treatment of primary pulmonary hypertension.Thorax 2001;56:888-90.

5. Oudiz R; Pulmonary Hypertension, Primary. eMedicine, August 2007. Available at URL: http://emedicine.medscape.com/ article/301450-overview

6. Yigla M, Kramer MR, Bendayan D, et al. Unexplained severe pulmonary hypertension in the elderly: report on 14 patients. Isr Med Assoc J 2004;6:78-81.

7. What is Pulmonary Hypertension? [editorial]. American Heart Association, Jun 2012. Available at URL:http://www.heart.org/ HEARTORG/ Conditions/HighBloodPressure/ AboutHighBloodPressure/What-is-Pulmonary-Hypertension_UCM_301792_Ar- ticle.jsp

8. Badesch DB, Raskob GE, Elliott CG, et al. Pulmonary hypertension: Baseline characteristics from the REVEAL Registry. Chest 2010;137:376-87.

9. Lapa M, Dias B, Jardim C, Fernandes CJ, et al. Cardiopulmonary manifestations of hepatosplenic schistosomiasis. Circulation 2009;119:1518-23.

10. Simonneau G, Robbins IM, Beghetti M, et al. Updated clinical classification of pulmonary hypertension. J Am Coll Cardiol 2009;54:S43-54

11. Rich S, Dantzker DR, Ayres SM, et al. Primary pulmonary hypertension. A national prospective study. Ann Intern Med 1987; 107:216-23

12. Thenappan T, Shah SJ, Rich S, Gomberg-Maitland M. A USAbased registry for pulmonary arterial hypertension: 1982-2006. Eur Respir J 2007;30:1103-10.

13. Chin KM, Rubin LJ. Pulmonary arterial hypertension, J Am Coll Cardiol 2008:51:1527-38

14. McLaughlin VV, Shillington A. Survival in primary pulmonary hypertension. The impact of epoprostenol therapy. Circulation 2002;106:1477-82

15. Runo JR, Loyd JE. Primary pulmonary hypertension. Lancet 2003;361:1533-44

16. Rubin LJ, Badesch DB. Evaluation and management of the patient with pulmonary arterial hypertension. Ann Intern Med 2005;143:282-92

17. Galie N, Hoeper MM, Humbert M, et al. Guidelines for the diagnosis and treatment of pulmonary hypertension: the Task Force for the Diagnosis and Treatment of Pulmonary Hypertension of the European Society of Cardiology (ESC) and the European Respiratory Society (ERS), endorsed by the International Society of Heart and Lung Transplantation (ISHLT). Eur Heart J 2009; 30:2493-537.

18. Peacock AJ; Treatment of pulmonary hypertension. BMJ 2003;326:835-6.

19. Galie N, Manes A, Negro L, Palazzini M, Bacchi Reggiani ML, Branzi A. A meta-analysis of randomized controlled trials in pulmonary arterial hypertension. Eur Heart J 2009;30:394-403.

20. Rich S, Kaufmann E, Levy PS. The effect of high doses of calciumchannel blockers on survival in primary pulmonary hypertension. N Engl J Med 1992;327:76-81.

21. Sitbon $\mathrm{O}$, Humbert $\mathrm{M}$, Jais $\mathrm{X}$, et al. Long-term response to calcium channel blockers in idiopathic pulmonary arterial hypertension. Circulation 2005;111:3105-11.

22. Mukerjee D, St George D, Coleiro B, et al. Prevalence and outcome in systemic sclerosis associated pulmonary arterial hypertension: application of a registry approach. Ann Rheum Dis 2003;62:1088-1093.

23. Petkov V, Mosgoeller W, Ziesche R, et al. Vasoactive intestinal peptide as a new drug for treatment of primary pulmonary hypertension. J Clin Invest 2003;111:1339-46.

24. Schermuly RT, Dony E, Ghofrani HA, et al. Reversal of experimental pulmonary hypertension by PDGF inhibition. J Clin Invest 2005;115:2811-21

25. Guignabert C, Izikki M, Tu LI, et al. Transgenic mice overexpressing the 5-hydroxytryptamine transporter gene in smooth muscle develop pulmonary hypertension. Circ Res 2006;98:1323-30.

26. Abe K, Shimokawa H, Morikawa K, et al. Long-term treatment with a Rho-kinase inhibitor improves monocrotaline-induced fatal pulmonary hypertension in rats. Circ Res 2004;94:385-93. 


\section{Sažetak}

Dobar efekat niskih doza blokatora kalcijumskih kanala kod bolesnice sa idiopatskom plućnom hipertenzijom

Olga Nedeljković-Arsenović1, Marija Boričić-Kostić2, Olivera Ninković-Mrđenovački ${ }^{3}$ Ivana Nedeljković1,2, Biljana Parapid ${ }^{1,2}$, Bosiljka Vujisić-Tešić1,2, Marko Banović1,2

${ }^{1}$ Medicinski fakultet, Univerzitet u Beogradu, dr Subotića 8, Beograd, Srbija; ${ }^{2}$ Klinika za kardiologiju, Klinički centar Srbije, Višegradska 26, Beograd, Srbija; Institut za javno zdravlje Šabac, Jovana Cvijića 1, Šabac, Srbija

Uvod: Plućna hipertenzija je hemodinamsko i patofiziološko stanje povećanog srednjeg arterijskog pritiska u plućnoj arteriji, preko $25 \mathrm{mmHg}$ u miru, procenjenog kateterizacijom desnog srca.

Prikaz bolesnika: Pacijentkinja starosti 44 godine dolazi na kardiološki pregled 13 godina nakon što joj je postavljena dijagnoza primarne plućne hipertenzije. Na koronarnim arterijama nisu viđene promene. Isključeno je postojanje sistemske bolesti vezivnog tkiva. Od tada do danas je na istoj terapiji - niskim dozama antagonista Ca (Nifelat $2 \times 10 \mathrm{mg}$ ) uz oralnu antikoagulantnu terapiju, stabilnog stanja, bez progresije tegoba. Zamara se isključivo pri većem fizičkom naporu, ponekad oseća ubrzani srčani rad i nesvesticu. Objektivno čujan sistolni šum uz naglašen drugi ton nad plućnom arterijom, elektrokardiogram sinusni ritam, inkompletni blok desne grane. Ehokardiografski pregled pokazuje znake plućne hipertenzije. Zaključak: Mali broj bolesnika sa plućnom hipertenzijom koja se odlikuje vazokonstriktornim svojstvima imaju dobru prognozu na terapiji visokim dozama kalcijumskih blokatora dok naša pacijentkinja ima dugogodišnji stabilan tok bolesti na niskoj dozi Ca blokatora.

Ključne reči: primarna plućna hipertenzija, blokatori Ca kanala, kateterizacija, ehokardiografija. 